\title{
Is Hepcidin a Good Marker for Inflammation in Obstructive Sleep Apnea Syndrome (OSAS) Patients?
}

\section{Obstrüktif Uyku Apne Sendromu Olan Hastalarda Hepsidin Iyi Bir Enflamasyon Belirteci midir?}

\author{
Hikmet Fırat, Cengiz Özdemir* , Esra Bilgin**, Faith S. Luyster***, Melike Yüceege, Murat Kızılgün****, Ahmet U. Demir**** , \\ Patrick J. Strollo******, Sadık Ardıç******
}

\author{
Dışkapı Yıldırım Beyazıt Training and Research Hospital, Clinic of Chest Diseases, Istanbul, Turkey \\ * Yedikule Training and Research Hospital, Clinic of Chest Diseases, Istanbul, Turkey \\ * Dr. Ali Menekşe Giresun Chest Diseases Hospital, Clinic of Chest Diseases, Giresun, Turkey \\ *** University of Pittsburgh School of Nursing, PA, USA \\ ****Dışkapı Child Diseases Hospital, Clinic of Biochemistry, Istanbul, Turkey \\ *****Hacettepe University Faculty of Medicine, Department of Chest Diseases Ankara, Turkey \\ ******Pittsburgh University Faculty of Medicine, Division of Pulmonary Allergy, and Critical Care, PA, USA \\ *******Kafkas University Faculty of Medicine, Department of Chest Diseases, Kars, Turkey
}

\section{Summary}

Objective: Obstructive Sleep Apnea syndrome (OSAS) is a clinical syndrome characterized by recurrent episodes of upper airway obstruction during sleep, resulting in chronic intermittent hypoxia and causing inflammation. IL- 6 and CRP are the most commonly studied inflammation biomarkers in OSAS. Given that IL-6 is an important activator of hepcidin during inflammation. In this study, hepcidin levels in OSAS patients were examined.

Materials and Methods: A total of 44 patients undergoing Polysomnography (PSG) for suspected sleep disorder breathing were studied. Patients were classified as having no to mild OSAS ( $n=15)$ or moderate to severe OSAS ( $n=29)$ based on apnea-hypopnea index (AHI) (AHI $<15$ vs. $A H I \geq 15$, respectively). Blood samples were obtained at night before PSG and in morning to obtain hepcidin levels.

Results: Patients with moderate to severe OSAS had lower evening hepcidin levels $(\mathrm{U}=-3.91, \mathrm{p}<.001)$ and a greater change in evening to morning hepcidin levels $(t=-2.83, p=.007)$ than patients with no or mild sleep apnea. AHI was negatively correlated with evening hepcidin (Hep E) ( $r s=-0.48, p=0.001)$ but was not significantly associated with morning hepcidin (Hep M) or change in evening to morning hepcidin levels. Greater Hep E levels were associated with significantly decreased odds of having moderate to severe sleep apnea even after controlling for covariates. A greater change in Hep E to Hep M levels were associated with a 1.08-fold increase in the odds of having moderate to severe sleep apnea (95\% Cl 1.02-1.15, $\mathrm{p}=.02)$.

Conclusion: This is a pioneer study to date to investigate the association between hepcidin and OSAS. Among patients with moderate-severe OSAS, significant increases in Hep E levels and change in Hep E to Hep M levels were found. Hepcidin may be a useful marker for the detection of hypoxia/reoxygenation episodes and inflammation in OSAS.

(JTSM 2015;2:33-7)

Key Words: Hepcidin, inflammation, obstructive sleep apnea syndrome

Conflicts of Interest: The authors reported no conflict of interest related to this article.

\section{Özet}

Amaç: Obstrüktif Uyku Apne sendromu (OUAS) uykuda defalarca üst solunum yolunun tıkanması ile karakterize klinik bir sendrom olup, kronik aralıklı hipoksi gelişimi sonucu dokuda enflamasyon oluşumuna neden olur. OUAS'da IL-6 ve CRP en sık araştırma yapılan enflamasyon biyobelirteçleridir. Enflamasyon gelissimi sırasında IL-6, hepsidinin önemli bir aktivatörüdür. Bu çalışmada OUAS'ı hastalarda hepsidin düzeyleri araştırılmıştır.

Gereç ve Yöntem: Uykuda solunum bozukluğu öntanısı ile polisomnografi uygulanan 44 hasta çalışmaya alınmıştır. Apne Hipopne Indeksine (AHI) göre $\mathrm{AHI} \geq 15$ olan 29 orta-ileri derece OUAS'lı hasta ve $A H \mathrm{I}<15$ olan hafif derece OUAS'I ı veya OUAS olmayan toplam 15 hasta çalışmaya alınmıştır. Tüm hastalardan Polisomnografi (PSG) öncesi (gece) ve PSG sonunda (sabah) hepsidin değerlerini tespit etmek amaçlı kan örnekleri alınmıştır. Bulgular: Orta-ağır derece OUAS'ı hastalarda gece hepsidin düzeyleri daha düşük bulunurken $(U=-3,91, p<, 001)$, gece-sabah hepsidin değerleri farkı yine orta-ağır OUAS'lı hastalarda hafif OUAS veya OUAS olmayan gruba göre çok daha yüksek bulunmuştur $(t=-2,83, p=, 007)$. AHI değeri gece ölçülen hepsidin (Hep E) ile negatif yönde korele bulunurken ( $r s=-$ $0,48, p=0,001)$, gündüz hepsidin değeri (Hep $M$ ) ve gece-gündüz farkı düzeyleri ile bağıntılı bulunmamıştır. Gece ölçülen hepsidin değerleri artışı kovaryanlar kontrol edildikten sonra dahi orta-ağır OUAS sıklığı ile negatif bağıntı bulunmuştur. Hep E ile Hep M arasındaki sayısal fark artışıyla orta-ağır derece OUAS sıklığında 1,08 kat artış tespit edilmiştir. (\%95 Cl 1,02-1,15, p=,02).

Sonuç: Bu araştırma; günümüze dek OUAS ve hepsidin arasındaki ilişkiyi araştıran öncü bir çalışmadır. Orta-ağır derece OUAS'lı hastalar içinde Hep E değerlerinde ciddi artış ve Hep E - Hep M değerleri farkında da ciddi değişiklikler bulunmuştur. Hepsidin, OUAS da hipoksi/reoksijenasyon epizodları ve enflamasyonu belirlemekte iyi bir biyobelirteç olabilir. (JTSM 2015:2:33-7)

Anahtar Kelimeler: Hepsidin, enflamasyon, obstrüktif uyku apne sendromu

Çıkar Çatışması: Yazarlar bu makale ile ilgili olarak herhangi bir çıkar çatışması bildirmemiştir. 


\section{Introduction}

Obstructive Apnea syndrome (OSAS) is characterized by repetitive periods of upper airway collapse resulting in cyclic periods of hypoxia/reoxygeneration and causing increased generation of oxygen species by oxidative stress (1). Chronic intermittent hypoxia or oxidative stress is critical for activation of nuclear factor (NF)- $\mathrm{B}$ (2,3). Activation of $N F-\kappa B$ induces expression of pro-inflammatory cytokines, including IL-6, which stimulate the production of C-reactive protein (CRP) by the liver (4).

Several inflammatory markers including CRP, tumor necrosis factor-alpha (TNF- $\alpha$ ) and interleukin-6 (IL-6) are increased in OSAS patients $(5,6)$. Chronic elevations in cytokines such as CRP and IL- 6 are associated with an increased risk of adverse health outcomes such as diabetes and heart disease (7-9). Systemic and airway inflammation in OSAS patients have been attributed to upper airway mechanical tissue injury and systemic hypoxemia and is hypothesized to contribute to daytime sleepiness and increased risk of cardiovascular complications and metabolic syndrome $(1,10)$.

CRP is a sensitive marker for systemic inflammation, and is higher in OSAS patients as compared to healthy controls (11). Markedly reductions in serum CRP and IL-6 levels have been demonstrated after one month of continuous positive airway pressure (CPAP) therapy even without a change in body mass index (BMI) (5).

Obesity itself is not only a well established risk factor for OSAS, but also a potent source of proinflammatory state (12). Macrophages of the adipose tissue secrete proinflammatory cytokines, such as TNF- $\alpha$ and IL-6 $(12,13)$. Numerous studies have shown that both total body fat and the amount of visceral fat are strong correlates of CRP levels (14-16).

Hepcidin is a 25 -amino acid protein. It regulates iron homeostasis, inhibites iron absorption at the enterocyte and sequesters iron at the macrophage, thus potentially contributing to decreased iron stores and hypoferremia $(17,18)$. The major regulatory action of hepcidin is to bind to and internalize the transmembrane iron efflux transporter, ferroportin, which is present on enterocytes, macrophages, and hepatocytes (19). Several studies have demonstrated that IL-6 is an important activator of hepcidin expression during inflammation (19-22). To date, no studies have examined the relation between hepcidin and OSAS. In the current study, we hypothesized that hepcidin may serve as a marker for inflammation in OSAS patients.

\section{Materials and Methods}

The study complied with the declaration of Helsinki and was approved by the local research ethics committee and informed consent was obtained from all participants.

\section{Study Population}

A total of 44 patients who were referred to the Sleep Clinic between January 2008-2009 were included in this study. All patients without anatomic dysfunction (severe nasal occlusion, septal deviation, retrognathia or micrognathia) with suspected sleep breathing disorders symptoms were accepted for polysomnography (PSG) and underwent a detailed physical examination. Patients who had chronic diseases (such as diabetes mellitus, chronic renal disease, chronic obstructive pulmonary disease) that could influence hepcidin metabolism and/or were on iron therapy or had hypoferritinemia $(<50$ $\mathrm{mcg} / \mathrm{L}$ ) were excluded from the study.

\section{Assessments}

Body Mass Index (BMI) was calculated as body weight/height 2 $\left(\mathrm{kg} / \mathrm{m}^{2}\right)$. Waist circumference and neck circumference were also measured. As part of the standard clinical assessment, blood pressure, blood count, liver and renal function tests, serum iron, total iron binding capacity, ferritin levels, spirometry, and a lipid and thyroid profile were obtained for all patients.

The Epworth Sleepiness Scale (ESS) is a self-administered eight-item questionnaire that is widely used for assessment of daytime sleepiness in adults. Validated Turkish version of ESS was used for this study (23).

\section{Polysomnography}

All participants underwent full-night PSG using the Compumedics E-series system (Compumedics ${ }^{\circledR}$, Melbourne, Victoria, Australia). The PSG recordings included 6-channels electroencephalography, 2-channels electrooculography, 2-channels submental electromyography, oxygen saturation by an oximeter finger probe, respiratory movements via chest and abdominal belts, airflow both via nasal pressure sensor and oronasal thermistor, electrocardiography, and leg movements via both tibial anterolateral electrodes. Sleep stages and respiratory parameters were scored according to the standard criteria of the American Academy of Sleep Medicine (AASM). Based on the 2007 AASM guidelines, apnea was defined as a $\geq 90 \%$ decrease in airflow persisting for at least 10 seconds relative to the basal amplitude. Hypopnea was defined as a $\geq 50 \%$ decrease in the airflow amplitude relative to the baseline value with an associated $\geq 3 \%$ oxygen desaturation or arousal persisting for at least 10 seconds (24).

Apnea-Hypopnea Index (AHI) was calculated based on the following formula: Total number of obstructive apneas+hypopneas/total sleep time (h). Patients with a sleep recording of $<5$ hours and sleep efficiency of $<60 \%$ were reevaluated. Patients were divided into two groups according to their AHI: $A H I<15$ representing no to mild OSAS $(n=15)$ and $A H I$ $\geq 15$ representing moderate to severe OSAS $(n=28)$.

\section{Hepcidin Blood Samples}

Blood samples for the evening hepcidin level (Hep E) were obtained between 21:00-22:00 pm before PSG and morning hepcidin levels (Hep $M$ ) were obtained between 06:00-07:00 am after PSG. The difference between Hep M -Hep E levels was calculated. Serum samples for hepcidin were centrifuged for 10 minutes at $3000 \mathrm{rpm}$ and stored at $-70^{\circ} \mathrm{C}$. A hepcidin prohormone enzyme-linked immunosorbent assay (ELISA) kit (RE 54051, IBL) was used for serum hepcidin measurement.

\section{Statistical Analyses}

Descriptive statistics for continuous variables were summarized as means \pm SDs or medians and interquartile range for variables that were not normally distributed. Categorical variables were described as frequencies with percentages. Spearman correlation coefficients were used to examine associations between continuous variables. Student's t test was used to 
compare the means of normally distributed variables between those with an $\mathrm{AHI}<15$ and $\mathrm{AHI} \geq 15$. Mann-Whitney $\mathrm{U}$ test was used for variables that were not normally distributed. Multivariable models were adjusted for age, sex, BMI, and waist circumference. Odds ratios (ORs) and $95 \%$ confidence intervals (95\% Cls) were reported. Statistical analysis was performed using SPSS, version 16.0 for windows.

\section{Results}

Table 1 displays the characteristics of the patients with no or mild OSAS and moderate to severe OSAS. The groups were similar with regards to age, sex, neck circumference, daytime sleepiness, and ferritin and CRP levels. Those with moderate to severe OSAS had, on average, higher BMI ( $t=-2.81, p=.008)$, greater waist circumference $(\mathrm{t}=-2.62, \mathrm{p}=.012)$, and higher oxygen desaturation index $(\mathrm{ODI})(\mathrm{t}=-6.15, \mathrm{p}<.001)$ than those with no or mild OSAS. Patients with moderate to severe OSAS had lower Hep $E$ levels $(U=-3.91, p<.001)$ than patients with no or mild sleep apnea and no difference in Hep $M$ was found between the groups. A greater change in Hep E to Hep M levels $(\mathrm{t}=-2.83, \mathrm{p}=.007)$ was found in patients with moderate to severe OSAS as compared to patients with no or mild OSAS, such that greater increases in hepcidin levels overnight occurred among those with no or mild OSAS Hep E, Hep M, and change in Hep E to Hep $M$ levels were not significantly correlated with age, $\mathrm{BMI}$, or neck and waist circumference. CRP was not significantly associated with $\mathrm{AHI}(r s=0.14, p=0.39)$, Hep $\mathrm{E}(\mathrm{rs}=0.17, \mathrm{p}=0.29)$, Hep $M(r s=-0.07, p=0.67)$, or change in Hep $E$ to Hep $M$ levels $(r s=-0.26, p=0.09)$. Hep $E$ was negatively correlated with $\mathrm{AHI}$

\begin{tabular}{|c|c|c|}
\hline Characteristic & $\mathrm{AHI}<15(\mathrm{n}=15)$ & AHI $\geq 15(n=29)$ \\
\hline Age, year & $42.0(13.3)$ & $46.7(7.3)$ \\
\hline Sex, \% (n) male & $86.7 \%(13)$ & $89.3 \%(25)$ \\
\hline $\mathrm{BMI}^{*}$ & $27.8(4.1)$ & $31.7(4.3)$ \\
\hline Waist Circumference, $\mathrm{cm}^{*}$ & $98.5(10.0)$ & $106.0(8.4)$ \\
\hline Neck Circumference $(\mathrm{cm})$ & $41.0(4.0)^{\mathrm{a}}$ & $41.3(3.3)^{\mathrm{a}}$ \\
\hline $\begin{array}{l}\text { Epworth Sleepiness } \\
\text { Scale Score }\end{array}$ & $11.2(6.2)$ & $11.4(5.3)$ \\
\hline Ferritin & $93.3(46.2)^{a}$ & $95.0(79.4)^{\mathrm{a}}$ \\
\hline $\mathrm{AHI}^{*}$ & $6.9(7.0)^{a}$ & $37.9(40.6)^{a}$ \\
\hline $\mathrm{ODI}^{*}$ & $7.6(4.8)$ & $41.1(20.7)$ \\
\hline $\begin{array}{l}\text { Oxygen desaturation } \\
<90 \% \text { (minutes) }^{*}\end{array}$ & $0.5(3.6)^{a}$ & $24.9(61.8)^{\mathrm{a}}$ \\
\hline $\begin{array}{l}\text { Oxygen desaturation } \\
<90 \%(\% \text { time) }\end{array}$ & $0.0(0.8)^{a}$ & $6.9(15.1)^{\mathrm{a}}$ \\
\hline Hepcidin (ng/ml) (evening) ${ }^{*}$ & $158.6(25.7)^{\mathrm{a}}$ & $140.2(29.2)^{a}$ \\
\hline Hepcidin (ng/ml) (morning) & $178.1(37.3)^{\mathrm{a}}$ & $163.0(34.8)^{\mathrm{a}}$ \\
\hline $\begin{array}{l}\Delta \text { Hepcidin (change from } \\
\text { evening to morning)* }\end{array}$ & $7.4(16.7)$ & $26.8(23.6)$ \\
\hline CRP & $3.0(1.2)^{a}$ & $4.1(3.0)^{a}$ \\
\hline
\end{tabular}

Note: Values represent means (SD) or amedian (interquartile range) depending on data distribution. BMI: Body mass index, AHI: Apnea hypopnea index, ODI: Oxygen desaturation index, CRP: C-reactive protein. Groups were compared using Student's t test or Mann-Whitney $U$ test where appropriate ${ }^{*} p<.01$ ${ }^{* *} \mathrm{p}<.05$ $(\mathrm{rs}=-0.48, \mathrm{p}=0.001)$, ODI $(\mathrm{rs}=-0.48, \mathrm{p}=0.001)$, minutes $\mathrm{O} 2$ $<90 \%(r s=-0.48, p=0.001)$, and \% time $02<90 \%$ ( $r s=-0.55$, $\mathrm{p}<0.001)$. Hep $\mathrm{M}$ was negatively correlated with ODI ( $\mathrm{rs}=-0.30$, $\mathrm{p}=.047)$. Change in Hep $\mathrm{E}$ to Hep $\mathrm{M}$ levels was correlated with $\%$ time $\mathrm{O} 2<90 \%$ ( $\mathrm{rs}=0.34, \mathrm{p}=.03$ ), but was not correlated with AHI, ODI, minutes O2 <90\%.

Table 2 and 3 show the ORs of having moderate to severe sleep apnea $(\mathrm{AHI} \geq 15)$, as computed with logistic regression models. Greater Hep E levels were associated with significantly decreased odds of having moderate to severe sleep apnea even after controlling for age, sex, BMI, and waist circumference $(\mathrm{OR}=0.78,85 \% \mathrm{Cl}=0.64-1.00, \mathrm{p}=.02)$. After adjusting for covariates, each 1-point increase in change in Hep E to Hep $M$ levels were associated with a 1.08-fold increase in the odds of having moderate to severe sleep apnea $(95 \% \mathrm{Cl} 1.02-1.15$, $\mathrm{p}=.02$ ).

\section{Discussion}

In the present study, it was shown that OSAS led to an increase in hepcidin levels througout the night, which in turn correlated with the markers indicating the levels of hypoxy periods reflecting the severity of OSA. Thus, hepcidin may be a useful marker in the determination of the complex relation between hypoxy and inflammation in OSA.

OSAS is an inflammatory disorder associated with increased levels of systemic IL-6, TNF-alpha, and CRP $(5,6,11,15)$. Repeated hypoxia-reoxygenation is associated with increased production of these inflammatory mediators. Studies report

\begin{tabular}{|l|l|l|l|}
\hline $\begin{array}{l}\text { Table 2. Odds ratios (95\% confidence interval) of having moderate } \\
\text { to severe sleep apnea by evening hepcidin levels }\end{array}$ \\
\hline & OR & $95 \% \mathrm{Cl}$ & p-value \\
\hline Model 1 & 1.05 & $0.97-1.14$ & 0.21 \\
\hline Age & 0.27 & $0.01-11.00$ & 0.49 \\
\hline Sex & 1.28 & $0.84-2.00$ & 0.26 \\
\hline BMI & 1.01 & $0.84-1.21$ & 0.91 \\
\hline Waist Circumference & \multicolumn{5}{|l}{} \\
\hline Model 2 & 0.78 & $0.64-1.00$ & 0.02 \\
\hline Hepcidin (evening)
\end{tabular}

BMI: Body mass index

\begin{tabular}{|c|c|c|c|}
\hline & OR & $95 \% \mathrm{Cl}$ & p-value \\
\hline \multicolumn{4}{|l|}{ Model 1} \\
\hline Age & 1.05 & $0.97-1.14$ & 0.21 \\
\hline Sex & 0.27 & $0.01-11.00$ & 0.49 \\
\hline $\mathrm{BMI}$ & 1.28 & $0.84-2.00$ & 0.26 \\
\hline Waist Circumference & 1.01 & $0.84-1.21$ & 0.91 \\
\hline \multicolumn{4}{|l|}{ Model 2} \\
\hline $\begin{array}{l}\Delta \text { Hepcidin } \\
\text { (change from evening to morning) }\end{array}$ & 1.08 & $1.02-1.15$ & 0.02 \\
\hline
\end{tabular}

BMI: Body mass index 
conflicting findings on CRP levels, including a decrease (26), increase (27) and no change (28). A diurnal variability of CRP in OSAS has been found, with lower levels during sleep and higher levels through the day (29). We found no correlation between CRP levels and AHI, although mean CRP levels were higher in moderate-severe OSAS group. These findings support prior studies that found no change in CRP levels. However, the results may be due to the fact that blood samples for CRP measurement were drawn in the morning or statistical difference between groups in terms of BMI.

It has been shown in various studies that blood levels of hepcidin, which play an important role in the regulation of iron metabolism, increase in chronic inflammatory states while they decrease in hypoxia $(30,32)$. Given the alternating hypoxy/reoxygenation periods throughout the night in OSA, it is likely that hepcidin levels will vary. In the present study, although evening hepcidin levels were found to be lower in the group with moderate-severe OSAS than the group with no or mild OSA, change in hepcidin levels were found to be higher in the group with moderate-severe OSA. This suggests that inflammation, induced by hypoxy/reoxygenation episodes repeated throughout the night, may account for the increase in morning hepcidin levels. We found those with moderate-severe OSAS had lower evening hepcidin levels. The observation that hepcidin levels increase throughout the night and decrease constantly over the day supports the idea that hepcidin has a diurnal rhythm (33). Decrease in evening levels of hepcidin in patients with moderate-severe OSAS may be related to the late effects of hypoxy episodes through the night. This suggests that there is a suppression of hepcidin through the day, because the same patients have high levels of hepcidin in the morning (just after sleep). This might be a compensation mechanism of the body, rather than due to anemia. Hepcidin blocks iron absorption and causes hypoferrinemia and chronic disease anemia, thus this mechanism may play an important role in OSAS and may help to explain why AHI was negatively correlated with evening hepcidin levels.

There was a significant increase of hepcidin levels from evening to morning in moderate-severe OSAS group. The major regulators of hepcidin blood levels are: Iron status, anemia, hypoxia and inflammation (34). Hepcidin synthesis is induced by iron loading and inflammation and suppressed by iron deficiency, hypoxia and erythropoesis. These complex regulations are not fully understood $(35,36)$, but the induction of hepcidin synthesis by inflammation has been shown to be interleukin-6-dependent $(22,37,38)$. Intermittent hypoxemia occurring in OSAS can stimulate transcription factors such as nuclear factor $-\kappa B$ and increase production of cytokines like IL-6 (39). Upper airway mechanical tissue injury and systemic hypoxia may contribute to inflammation in OSAS $(1,10)$. The inflammatory mechanism may explain the meaningful increase of hepcidin during sleep in OSA.

Inflammation is one of the major regulators of rapid increase of hepcidin levels and consequent induction of hypoferremia $(19,22)$. On the other hand, using animal models, it was demonstrated that hepcidin could be repressed despite inflammation $(40,41)$.

Blood hepcidin levels change in a similar manner of ferritin. Both hepcidin and ferritin levels decrease with low iron stores and increase as storage iron increases. Similar to ferritin, hepcidin increases with inflammation, confounding the evaluation of iron status (42). None of our patients have hypoferrinemia (because of exclusion criteria), thus none of them have high hepcidin levels during the daytime.

Obesity itself causes chronic inflammation which is related with the expression of pro-inflammatory cytokines such as IL-6 and TNF- $\alpha$. (43). IL-6 is shown to be an important activator of hepcidin expression during inflammation in several studies $(20,22,38)$. Also elevated levels of hepcidin in tissue of severe obese patients and positive correlation between adipocyte hepcidin expression and BMI were demonstrated (44).

There are some limitations of the present study. The study groups included few numbers of cases and the control group was not composed of completely healthy individuals. The fact that we did not use more sensitive markers for inflammation in OSAS such as "IL-6" and "high sensitive CRP" might have contributed to the insignificant correlations between CRP levels and data such as $\mathrm{AHI}$ and ODI, which reflect the severity of OSA.

\section{Discussion}

OSAS is characterized by repetitive periods of upper airway collapse resulting in cyclic periods of hypoxia/reoxygeneration and causes increased generation of oxygen species by oxidative stress and inflammation. Several studies have demonstrated that IL-6 is an important activator of hepcidin expression during inflammation. Among patients with moderate-severe OSA, significant increases in Hep E levels and change in Hep E to Hep $M$ levels were found. Hepcidin may be a useful marker for the detection of hypoxy/reoxygenation episodes and inflammation in OSA.

\section{References}

1. Lavie L. Obstructive sleep apnoea syndrome--an oxidative stress disorder. Sleep Med Rev 2003;7:35-51.

2. Li Q, Verma IM. NF-kappaB regulation in the immune system. Nat Rev Immunol 2002;2:725-34.

3. Greenberg H, Ye X, Wilson D, Htoo AK, Hendersen T, Liu SF. Chronic intermittent hypoxia activates nuclear factor-kappaB in cardiovascular tissues in vivo. Biochem Biophys Res Commun 2006;343:591-6.

4. Hansson GK. Inflammation, atherosclerosis, and coronary artery disease. N Engl J Med 2005;352:1685-95.

5. Yokoe T, Minoguchi K, Matsuo $H$, Oda N, Minoguchi $H$, Yoshino G, Hirano T, Adachi M. Elevated levels of C-reactive protein and interleukin- 6 in patients with obstructive sleep apnea syndrome are decreased by nasal continuous positive airway pressure. Circulation 2003; 107:1129-34.

6. Minoguchi K, Tazaki T, Yokoe T, Minoguchi H, Watanabe Y, Yamamoto $\mathrm{M}$, Adachi M. Elevated production of tumor necrosis factor-alpha by monocytes in patients with obstructive sleep apnea syndrome. Chest 2004; 126:1473-9.

7. Ridker PM, Cushman M, Stampfer MJ, Tracy RP, Hennekens $\mathrm{CH}$. Inflammation, aspirin, and the risk of cardiovascular disease in apparently healthy men. N Engl J Med 1997;336:973-9.

8. Ridker PM, Rifai N, Stampfer MJ, Hennekens CH. Plasma concentration of interleukin-6 and the risk of future myocardial infarction among apparently healthy men. Circulation 2000;101:1767-72.

9. Pradhan $A D$, Manson JE, Rifai N, Buring JE, Ridker PM. C-reactive protein, interleukin 6 , and risk of developing type 2 diabetes mellitus. JAMA 2001;286:327-34. 
10. Hatipoğlu U, Rubinstein I. Inflammation and obstructive sleep apnea syndrome pathogenesis: a working hypothesis. Respiration 2003;70:665-71.

11. Shamsuzzaman AS, Winnicki M, Lanfranchi P, Wolk R, Kara T, Accurso $\mathrm{V}$, Somers VK. Elevated C-reactive protein in patients with obstructive sleep apnea. Circulation 2002;105:2462-4.

12. Alam I, Lewis K, Stephens JW, Baxter JN. Obesity, metabolic syndrome and sleep apnoea: all pro-inflammatory states. Obes Rev 2007;8:119-27.

13. Fantuzzi G. Adipose tissue, adipokines, and inflammation. J Allergy Clin Immunol 2005;115: 911-9.

14. Panagiotakos DB, Pitsavos C, Yannakoulia M, Chrysohoou C, Stefanadis C. The implication of obesity and central fat on markers of chronic inflammation: The ATTICA study. Atherosclerosis 2005;183:308-15.

15. Saijo Y, Kiyota N, Kawasaki Y, Miyazaki Y, Kashimura J, Fukuda M, Kishi R. Relationship between C-reactive protein and visceral adipose tissue in healthy Japanese subjects. Diabetes obes metab 2004;6:249-58.

16. Rexrode KM, Pradhan A, Manson JE, Buring JE, Ridker PM. Relationship of total and abdominal adiposity with CRP and IL-6 in women. Ann epidemiol 2003;13:674-82.

17. Knutson MD, Oukka M, Koss LM, Aydemir F, Wessling-Resnick M. Iron release from macrophages after erythrophagocytosis is up-regulated by ferroportin 1 overexpression and down-regulated by hepcidin. Proc Natl Acad Sci U S A, 2005; 102:1324-8.

18. Hunter HN, Fulton DB, Ganz T, Vogel HJ. The solution structure of human hepcidin, a peptide hormone with antimicrobial activity that is involved in iron uptake and hereditary hemochromatosis. J Biol Chem 2002;277:37597-603.

19. Nemeth E, Ganz T. Regulation of iron metabolism by hepcidin. Annu Rev Nutr 2006;26:323-42.

20. Park $\mathrm{CH}$, Valore EV, Waring AJ, Ganz T. Hepcidin, a urinary antimicrobial peptide synthesized in the liver. J Biol Chem 2001;276:7806-10.

21. Ganz T. Hepcidin in iron metabolism. Curr Opin Hematol 2004; 11:251-4.

22. Nemeth E, Rivera S, Gabayan V, Keller C, Taudorf S, Pedersen BK, Ganz T . IL-6 mediates hypoferremia of inflammation by inducing the synthesis of the iron regulatory hormone hepcidin. J Clin Invest 2004;113:1271-6.

23. Izci B, Ardic S, Firat H, Sahin A, Altinors M, Karacan I. Reliability and validity studies of the Turkish version of the Epworth Sleepiness Scale. Sleep Breath 2008;12:161-8.

24. Iber C, Ancoli-Israel, Chesson A, and Quan SF The American Academy of Sleep Medicine. The AASM Manual for the Scoring of $S$ leep and Associated Events: Rules, Terminology and Technical Specifications, 1st ed. Westnchester, Illinois:AASM,2007

25. Vgontzas AN, Papanicolaou DA, Bixler EO, Kales A, Tyson K, Chrousos GP. Elevation of plasma cytokines in disorders of excessive daytime sleepiness: role of sleep disturbance and obesity. J Clin Endocrinol Metab 1997;82:1313-6.

26. Frey DJ, Fleshner M, Wright KP Jr. The effects of 40 hours of total sleep deprivation on inflammatory markers in healthy young adults. Brain Behav Immun 2007;21:1050-7.
27. Meier-Ewert HK, Ridker PM, Rifai N, Regan MM, Price NJ, Dinges DF, Mullington JM. Effect of sleep loss on C-reactive protein, an inflammatory marker of cardiovascular risk. J Am Coll Cardiol 2004;43:678-83.

28. Dimitrov S, Lange T, Benedict C, Nowell MA, Jones SA, Scheller J, Rose-John S, Born J. Sleep enhances IL-6 trans-signaling in humans. FASEB J 2006;20:2174-6.

29. Mills PJ, Natarajan L, von Känel R, Ancoli-Israel S, Dimsdale JE. Diurnal variability of C-reactive protein in obstructive sleep apnea. Sleep Breath 2009;13:415-20.

30. Nicolas G, Chauvet C, Viatte L, Danan JL, Bigard X, Devaux I, Beaumont C, Kahn A, Vaulont $S$. The gene encoding the iron regulatory peptide hepcidin is regulated by anemia, hypoxia, and inflammation. J Clin Invest 2002;110:1037-44.

31. Nicolas G, Bennoun M, Porteu A, Mativet $S$, Beaumont $C$, Grandchamp B, Sirito M, Sawadogo M, Kahn A, Vaulont S. Severe iron deficiency anemia in transgenic mice expressing liver hepcidin. Proc Natl Acad Sci U S A 2002;99:4596-601.

32. Lee P, Peng $H$, Gelbart T, Beutler E. The IL-6- and lipopolysaccharideinduced transcription of hepcidin in HFE-, transferrin receptor 2-, and beta 2-microglobulin-deficient hepatocytes. Proc Natl Acad Sci U S A 2004; 101:9263-5.

33. Troutt JS, Rudling M, Persson L, Ståhle L, Angelin B, Butterfield AM, Schade $A E$, Cao G, Konrad RJ. Circulating human hepcidin- 25 concentrations display a diurnal rhythm, increase with prolonged fasting, and are reduced by growth hormone administration. Clin Chem 2012;58:1225-32.

34. Coyne DW. Hepcidin: clinical utility as a diagnostic tool and therapeutic target. Kidney Int 2011;80:240-4.

35. Young B, Zaritsky J. Hepcidin for clinicians. Clin J Am Soc Nephrol 2009;4:1384-7.

36. Hentze MW, Muckenthaler MU, Galy B, Camaschella C. Two to tango: regulation of Mammalian iron metabolism. Cell 2010;142:24-38.

37. Weiss G, Goodnough LT. Anemia of chronic disease. N Engl J Med 2005;352:1011-23.

38. Wrighting DM, Andrews NC. Interleukin-6 induces hepcidin expression through STAT3. Blood 2006;108:3204-9.

39. Semenza GL. Hypoxia-inducible factor 1: control of oxygen homeostasis in health and disease. Pediatr Res 2001;49:614-7.

40. Huang $H$, Constante M, Layoun A, Santos MM. Contribution of STAT3 and SMAD4 pathways to the regulation of hepcidin by opposing stimuli. Blood 2009;113:3593-9.

41. Lasocki S, Millot S, Andrieu V, Lettéron P, Pilard N, Muzeau F, Thibaudeau $\mathrm{O}$, Montravers P, Beaumont C. Phlebotomies or erythropoietin injections allow mobilization of iron stores in a mouse model mimicking intensive care anemia. Crit Care Med 2008;36:2388-94.

42. Coyne D. Iron indices: what do they really mean? Kidney Int Suppl 2006:4-8.

43. Greenberg AS, Obin MS. Obesity and the role of adipose tissue in inflammation and metabolism. Am J Clin Nutr 2006;83:461-5.

44. Bekri S, Gual P, Anty R, Luciani N, Dahman M, Ramesh B, lannelli A, Staccini-Myx A, Casanova D, Ben Amor I, Saint-Paul MC, Huet PM, Sadoul JL, Gugenheim J, Srai SK, Tran A, Le Marchand-Brustel Y. Increased adipose tissue expression of hepcidin in severe obesity is independent from diabetes and NASH. Gastroenterology 2006;131:788-96. 